\title{
Penerapan Model Pembelajaran REACT-TPK terhadap Pemahaman Konsep Siswa dengan Kemampuan Awal Berbeda
}

\author{
Wahyu Setyowati ${ }^{1}$, Suhadi Ibnu ${ }^{1}$, Irma Kartika Kusumaningrum ${ }^{1}$ \\ ${ }^{1}$ Pendidikan Kimia-Universitas Negeri Malang
}

\begin{tabular}{l}
\hline \hline INFO ARTIKEL \\
\hline Riwayat Artikel: \\
Diterima: 11-12-2019 \\
Disetujui: $20-03-2019$ \\
\hline
\end{tabular}

Kata kunci:

REACT-TPK;

concept understanding;

initial ability is different;

REACT-TPK,

pemahaman konsep;

kemampuan awal berbeda

\begin{abstract}
ABSTRAK
Abstract: The purpose of this study is determine the effect of applying REACT-TPK model on students' concept understanding. Two groups of students which were compare had different prior knowledge. The REACT-TPK model is one of the number innovations in chemistry learning model thst was applied in order to improve students' understanding of chemistry concepts. The model can make students construct concepts actively and also encourages student's conceptual change from misconceptions to correct understanding. Students' prior knowledge scores were obtained from previous relevant topic test scores. Test instrument was in the form multiple choice questions with closed reason accompanied by $C R I$ and multiple-choice questions with $84,37 \%$ content validity and reliability (r) 0.740 for multiple-choice questions with closed-reason and (r) 0.599 for multiple-choice question. Data analysis using two way ANOVA test. The results showed there were differences in concept understanding between experimental and control classes (Sig.2-tailed 0.037), concept understanding between high initial ability students and low initial ability were different (Sig.2-tailed 0.002), but no interaction between learning models with initial level ability toward understanding of students concepts (Sig.2-tailed 0.395).
\end{abstract}

\begin{abstract}
Abstrak: Penelitian ini bertujuan mengetahui efek dari pengimplementasian model REACT-TPK terhadap pemahaman konsep siswa. Dua kelompok siswa yang dibandingkan mempunyai kemampuan awal berbeda. REACT-TPK ialah satu dari sejumlah inovasi pada pembelajaran kimia yang diaplikasikan demi meningkatkan pemahaman konsep kimia siswa karena dapat membuat siswa aktif mengonstruk konsep dan juga mendorong terjadinya perubahan konsepsi siswa dari salah menjadi benar. Nilai kemampuan awal diperoleh dari nilai ulangan harian topik sebelumnya. Instrumen tes berupa soal pilihan ganda beralasan tertutup disertai $C R I$ dan soal pilihan ganda saja. Validitas isi instrumen tes $84,37 \%$ serta reliabilitasnya (r) 0,740 untuk soal pilihan ganda beralasan tertutup disertai $C R I$ dan (r) 0,599 untuk soal pilihan ganda. Data dianalisa dengan two way ANOVA test. Hasil dari penelitian yakni ada beda pemahaman konsep diantara siswa yang diimplementasikan model REACT-TPK dan REACT saja (Sig.2tailed 0,037), ada beda pemahaman konsep diantara siswa berkemampuan awal tinggi serta rendah (Sig.2-tailed 0,002), tetapi tidak ditemukan adanya dampak pengiring antara model pembelajaran dan tingkat kemampuan awal pada pemahaman konsep siswa (Sig.2tailed 0,395 ).
\end{abstract}

\section{Alamat Korespondensi:}

Wahyu Setyowati

Pendidikan Kimia

Universitas Negeri Malang

Jalan Semarang 5 Malang

E-mail: wahyusetyowati026@gmail.com

Banyak riset yang telah menguji perbedaan kinerja siswa pada pemahaman konseptual dan algoritmik (Niaz \& Chac'on, 2003). Pembelajaran IPA khususnya kimia tidak hanya melibatkan pemahaman konseptual tetapi juga pemahaman algoritmik sehingga dalam belajar kimia siswa diharapkan tidak hanya dapat menghitung atau menerapkan rumus tetapi pemahaman konsepnya juga harus bagus. Jika pemahaman konsep yang dimiliki siswa bagus, diharapkan mampu menerapkan konsepnya yang dipahami tersebut untuk memecahkan permasalahan kimia. Namun, pada kenyataannya, mayoritas siswa memecahkan permasalahan kimia hanya dengan cara algoritmik dan tidak dapat mengaitkan dengan konsep terkait karena keterbatasan pemahaman konsep kimia (Gabel, Sherwood, \& Enochs, 1984; Holme, Luxford, \& Brandriet, 2015). 
Salah satu penyebab siswa kurang memahami konsep yang mendasari permasalahan kimia adalah adanya hambatan berupa miskonsepsi (Cetin-Dindar \& Geban, 2017). Miskonsepsi menyebabkan interpretasi siswa berbeda dengan interpretasi yang diterima para ahli (Nakhleh, 1992). Banyak juga penelitian yang telah menunjukkan bahwa siswa dari berbagai usia memiliki miskonsepsi yang beragam dalam berbagai topik sains (Yuruk, 2007). Salah satu bidang penelitian tentang miskonsepsi siswa adalah miskonsepsi pada mata pelajaran kimia.

Kimia ialah salah satu kajian yang membuat siswa memiliki banyak miskonsepsi (Cetin, Kaya, \& Geban, 2009). Salah satu topik dalam pelajaran kimia yang banyak ditemui terjadinya miskonsepsi adalah topik larutan penyangga. Topik ini memiliki sejumlah karakteristik, yaitu bersifat abstrak dan mengharuskan penguasaan banyak konsep pada topik sebelumnya (Orgill \& Sutherland, 2008). Ciri khas yang lainnya, yakni sewaktu mempelajari larutan penyangga, siswa terlebih dahulu harus memahami konsep fundamental kimia mulai dari aspek makroskopis, submikroskopis, dan simbolik, kemudian mengintegrasikan pemahaman tentang konsep larutan penyangga pada ketiga aspek tersebut (Orgill \& Sutherland, 2008). Keabsurdan serta kekompleksan dari topik ini bikin siswa banyak yang mengalami kesulitan dalam mempelajarinya. Kesulitan-kesulitan yang dialami oleh siswa dapat menimbulkan miskonsepsi.

Miskonsepsi yang sudah melekat pada pemikiran siswa akan sangat sulit dihilangkan. Beberapa hasil riset dari (Aprilia \& Suyono, 2016; Ardyanti \& Nasrudin, 2014; Nikmah \& Suyono, 2015) menunjukkan bahwa kegiatan remedial masih menyisakan miskonsepsi. Menanggapi hal tersebut, maka perlakuan dini terhadap miskonsepsi perlu dilakukan, yaitu dengan melakukan prevensi. Kegiatan prevensi ini dilakukan dengan mengaplikasikan model pembelajaran tertentu demi memperbaiki pemahaman konsep siswa. Selain membelajarkan konsep-konsep, upaya prevensi ini juga memberikan penegasan pada konsepkonsep yang mengarah ke miskonsepsi. Upaya prevensi ini dinilai lebih efektif dari segi waktu dan tenaga dibandingkan pembelajaran remedial. Model pembelajaran berlandaskan teori konstruktivik dapat diterapkan sebagai upaya prevensi (Ahmad, Suyono, \& Yuanita, 2013; Muallifah, Suyono, \& Yuanita, 2013). Salah satunya adalah REACT.

REACT ialah model pembelajaran dengan pendekatan berbasis konteks. Teori konstruktivistik merupakan landasan pembelajaran kontekstual yang menandaskan bahwa pengalaman siswa yang sedang berlangsung dikaitkan dengan pengetahuan yang akan dibangun (Kalchick \& Oertle, 2010). Penggunaan konteks dan aplikasi pada pembelajaran kontekstual merupakan titik awal dalam mengembangkan pemahaman konsep ilmiah (Bennett, Grasel, Parchmann, \& Waddington, 2005). Penerapan REACT mampu memperbaiki pemahaman konseptual, mengurangi miskonseps serta ketidakpahaman konsep (Karsli \& Yigit, 2017; Suminten, 2015).

Tahapan REACT ada lima, yakni Relating, Experiencing, Applying, Cooperating, dan Transferring (Crawford, 2001). Pada tahapan relating, siswa diajak menyangkutpautkan topik yang sedang ditelaah dengan pengalaman keseharian mereka atau mengaitkan pengetahuan yang lama dengan baru. Pengaitan ini dapat dilakukan dengan pemberian fenomena sehari-sehari. Fenomena yang diberikan haruslah yang sesuai dengan topik yang akan dipelajari agar siswa tidak salah mengaitkan dan tidak menimbulkan miskonsepsi. Tahap experiencing merupakan proses eksplorasi dan penemuan konsep. Tahap ini mengajak siswa untuk aktif dalam menemukan konsep sendiri. Dalam proses penemuan konsep ini, siswa tidak akan dilepas begitu saja, akan tetapi guru sebagai fasilitator akan memvasilitasi dan membimbing siswa secukupnya agar proses pemerolehan konsep siswa terarah dan meminimalisir terjadinya miskonsepsi. Tahap applying merupakan tahap penerapan konsep. Konsep yang sudah diperoleh pada tahap sebelumnya akan dipakai untuk memecahkan masalah kimia. Tahap cooperating bertujuan agar siswa belajar dengan bertukar informasi dan berkomunikasi dengan lingkungan sosial mereka. Pada tahap transferring, siswa diberi kesempatan untuk mentransfer konten ke situasi atau konteks baru, dan untuk memperdalam informasi yang dipelajari. Topik pelajaran yang diajarkan menggunakan model pembelajaran REACT memiliki pengaruh positif pada pemahaman para siswa (Ultay, Durukan, \& Ultay, 2015).

Sebaik apapun upaya prevensi yang dilakukan, peluang untuk terjadinya miskonsepsi dikhawatirkan masih dapat ditemukan. Kegiatan pencegahan miskonsepsi dengan menggunakan strategi berbasis konstruktivistik mampu meningkatkan pemahaman konsep dan mengurangi jumlah siswa yang mengalami miskonsepsi serta tidak paham konsep (Ahmad et al., 2013; Muallifah et al., 2013), namun kegiatan prevensi tersebut masih juga menyisakan miskonsepsi di akhir permbelajaran. Berdasarkan alasan tersebut, maka strategi tambahan sangat diperlukan agar miskonsepsi yang tersisa di akhir pembelajaran bisa lebih terminimalkan lagi.

Strategi yang telah dikembangkan berdasarkan teori perubahan konsep terbukti efektif dalam mencegah miskonsepsi (Maratusholihah, Rahayu, \& Fajaroh, 2017). TPK (Teks Perubahan Konsep) adalah teks yang dikembangkan berdasarkan pendekatan perubahan konsep dan dirancang untuk mengubah konsepsi awal siswa yang salah menjadi benar. TPK memberikan konstribusi yang positif dalam membenahi miskonsepsi di semua bidang (Cepni \& Cil, 2010). Selain itu, beberapa penelitian lain menunjukkan bahwa TPK effektif untuk meningkatkan pemahaman konsep siswa pada topik pelajaran kimia (Beerenwinkel, Parchmann, \& Grasel, 2011; Demircioglu, 2009; Durmus \& Bayraktar, 2010; Sendur \& Toprak, 2013), sehingga tidak menutup kemungkinan bahwa TPK dapat digunakan untuk mencegah miskonsepsi selama pembelajaran berlangsung. Ada empat kondisi yang harus diikuti untuk terjadi perubahan konsep, yaitu (1) dissatisfaction phase, (2) the intelligibility phase, (3) plausibility phase, dan (4) The fruitfulness phase (Posner, Strike, Hewson, \& Gertzog, 1982). 
TPK yang dikembangkan terdiri dari tiga bagian. Bagian satu akan diberikan kepada siswa pada tahapan applying dalam model pembelajaran REACT yaitu tahapan setelah siswa memiliki konsepsi awal. Bagian dua akan diberikan pada tahapan cooperating. Bagian tiga akan diberikan pada tahapan transferring. Pada awal TPK, siswa diberikan situasi atau pertanyaan yang memungkinkan siswa untuk mengemukakan konsepsi awal yang dimilikinya, kemudian disajikan informasi berkaitan tentang kemungkinan miskonsepsi yang dominan, serta penyajian tentang penjelasan ilmiah (Cil \& Cepni, 2016). Teks-teks ini disediakan untuk membuat siswa sadar akan kekurangan pengetahuan mereka dan untuk menciptakan konflik konseptual atau konflik kognitif (Sung-Il Kim \& Dusen, 1998). Siswa akan merasa tidak puas dan merasa ragu-ragu terhadap gagasan awalnya sehingga dengan adanya keraguan tersebut membuat siswa berkeinginan untuk mengonstruksi konsepnya yang salah menjadi benar. Jika hal tersebut dapat terjadi pada proses pembelajaran, maka kemungkinan besar TPK ini dapat digunakan untuk mencegah miskonsepsi yang berpotensi terjadi selama proses pembelajaran berlangsung.

Aspek yang dapat memengaruhi keberhasilan siswa dalam memahami konsep larutan penyangga ada dua, yakni aspek ekstern (misal, metode mengajar guru) dan aspek intern (misal, kemampuan awal) (Ahmad, Gani, \& Tanre, 2017). Kemampuan awal dikatakan dapat memengaruhi hasil belajar sebab mendeskrispsikan kesiapan siswa saat mengikuti pembelajaran pada topik baru (Herawati, Mulyani, \& Redjeki, 2013).

\section{METODE}

Factorial design $2 \times 2$ digunakan pada penelitian ini. Uji homogenitas dan normalitas dilalukan terhadap nilai kemampuan awal populasi penelitian (ada enam kelas). Sampel ditentukan secara acak menggunakan cluster random sampling technique dan diperoleh dua kelas, yakni kontrol dan eksperimen. Nilai kemampuan awal kedua kelas ini diuji homogenitas, normalitas, dan kesamaan rata-rata. Selanjutnya, dilakukan pengkategorian siswa berdasarkan tingkat kemampuan awal dan diperoleh kelompok berkemampuan awal tinggi dan rendah.

Tabel 1. Factorial Design $2 x 2$

\begin{tabular}{lcc}
\hline \multirow{2}{*}{ Tingkat Kemampual Awal (KA) } & \multicolumn{2}{c}{ Model Pembelajaran } \\
\cline { 2 - 3 } & $\boldsymbol{R}$ EAC -TPK $\left(\mathrm{A}_{1}\right)$ & REACT $\left(\mathrm{A}_{2}\right)$ \\
\hline Tinggi $\left(\mathrm{B}_{1}\right)$ & $\mathrm{A}_{1} \mathrm{~B}_{1}$ & $\mathrm{~A}_{2} \mathrm{~B}_{1}$ \\
Rendah $\left(\mathrm{B}_{2}\right)$ & $\mathrm{A}_{1} \mathrm{~B}_{2}$ & $\mathrm{~A}_{2} \mathrm{~B}_{2}$ \\
\hline
\end{tabular}

Keterangan:

$\mathrm{A}_{1} \mathrm{~B}_{1}=$ pemahaman konsep siswa berkemampuan awal tinggi sewaktu dibelajarkan dengan REACT-TPK.

$\mathrm{A}_{1} \mathrm{~B}_{2}=$ pemahaman konsep siswa berkemampuan awal rendah sewaktu dibelajarkan dengan REACT-TPK

$\mathrm{A}_{2} \mathrm{~B}_{1}=$ pemahaman konsep siswa berkemampuan awal tinggi saat diajarkan menggunakan REACT saja.

$\mathrm{A}_{2} \mathrm{~B}_{2}=$ pemahaman konsep siswa berkemampuan awal rendah saat diajarkan menggunakan REACT saja.

\section{HASIL}

Skor siswa diperoleh dari tes pemahaman konsep larutan penyangga (TPKLP) yang tersusun atas 29 pertanyaan (15 soal pilihan ganda beralasan tertutup disertai CRI dan 14 soal pilihan ganda). Berikut ini rerata pretest beserta posttest kelas kontrol dan eksperimen.

Tabel 2. Rerata Pretest beserta Posttest

\begin{tabular}{ccc}
\hline Kelas & Rerata Pretest & Rerata Posttest \\
\hline Kontrol (KK) & 19,35 & 59,40 \\
Eksperimen (KE) & 19,13 & 66,07 \\
\hline
\end{tabular}

Data pada tabel 2 menyatakan baik rerata kelas kontrol maupun eksperimen sama-sama mengalami kenaikan dari pretest ke posttest. Rerata siswa kelas kontrol mengalami kenaikan senilai 40,05 sedangkan kelas eksperimen mengalami kenaikan senilai 46,94. Hal tersebut menyiratkan bahwasanya kenaikan rerata siswa kelas eksperimen lebih tinggi daripada kontrol. Data nilai pretest dan posttest diuji prasyarat dulu sebelum diuji hipotesis dan hasilnya ditunjukkan pada tabel 3.

Tabel 3. Data Hasil Uji Prasyarat

\begin{tabular}{cccccc}
\hline \multirow{2}{*}{$\begin{array}{c}\text { Nilai } \\
\text { Test }\end{array}$} & Kelas & \multicolumn{2}{c}{ Uji Normalitas } & \multicolumn{2}{c}{ Uji Homogenitas } \\
\cline { 3 - 4 } Pre & & Sig. & Simpulan & Sig. & Simpulan \\
\cline { 2 - 4 } & Kontrol (KK) & 0,160 & Normal & \multirow{2}{*}{0,219} & \multirow{2}{*}{ Homogen } \\
\cline { 2 - 4 } Post & Eksperimen (KE) & 0,089 & Normal & & \\
\cline { 2 - 4 } & Kontrol (KK) & 0,136 & Normal & \multirow{2}{*}{0,527} & \multirow{2}{*}{ Homogen } \\
\cline { 2 - 4 } & Eksperimen (KE) & 0,192 & Normal & & \\
\hline
\end{tabular}


Berdasarkan tabel 3, nilai signifikansi hasil uji homogenitas dan normalitas pretest ataupun posttest $>0,05$ sehingga dapat disimpulkan bahwa data bersifat homogen dan terdistribusi normal. Data yang homogen dan terdistribusi normal merupakan syarat dilakukannya uji parametrik. Uji hipotesis pada penelitian ini menggunakan Two Way Anova Test yang merupakan salah satu uji parametrik dan hasil ujinya tertera pada tabel 4.

Tabel 4. Data Hasil Uji Hipotesis Menggunakan Two Way Anova

\begin{tabular}{lccccc}
\hline \multicolumn{1}{c}{ Source } & Type III Sum of Squares & df & Mean Square & \multicolumn{1}{c}{ F } & Sig. \\
\hline Model Pembelajaran (MP) & 649,167 & 1 & 649,167 & 4,577 &, 037 \\
Kemampuan Awal (KA) & 1538,498 & 1 & 1538,498 & 10,848 &, 002 \\
\hline $\begin{array}{l}\text { Model Pembelajaran (MP) * } \\
\text { Kemampuan Awal (KA) }\end{array}$ & \multirow{2}{*}{104,202} & 1 & \multirow{2}{*}{104,202} & \multirow{2}{*}{, 735} & \multirow{2}{*}{, 395} \\
\hline
\end{tabular}

Berdasarkan tabel 4, kesimpulan yang dapat diambil ialah ada perbedaan pemahaman konsep antara siswa yang diajar menggunakan model pembelajaran REACT-TPK dan REACT saja, ada beda pemahaman konsep antara siswa berkemampuan awal tinggi dan rendah pada topik larutan penyangga, dan tidak ditemukan adanya dampak pengiring antara model pembelajaran dan tingkat kemampuan awal pada pemahaman konsep pada topik larutan penyangga.

\section{PEMBAHASAN}

Hasil pada pengujian hipotesis menunjukkan bahwasanya ada beda pemahaman konsep antara siswa kelas eksperimen dan kontrol. Berdasarkan data nilai rerata test dari pre ke post pada tabel 2, kelas eksperimen maupun kontrol sama-sama menunjukkan adanya kenaikan rerata. Rerata skor gain siswa kelas kontrol sebesar 40,05 dan eksperimen sebesar 46,94. Kedua kelas menunjukkan adanya kenaikan pemahaman konsep dikarenakan kedua kelas sama-sama diimplementasikan pembelajaran REACT. Pengaplikasian konteks yang relevan dalam model pembelajaran REACT mampu membantu siswa untuk memperbaiki miskonsepsi pada topik kimia dan efektif membantu siswa menghubungkan konsep ilmiah dengan konteks terkait, sehingga mampu meningkatkan pemahaman konsep siswa pada topik kimia (Karsli \& Yigit, 2017; Ultay et al., 2015). Penerapan REACT juga mampu meningkatkan pencapaian siswa pada topik kimia (Gunter, 2018). Namun, siswa di kelas eksperimen menunjukkan kenaikan rerata yang lebih tinggi dibanding kelas kontrol. Hal ini mengindikasikan bahwa siswa yang diajar dengan REACT-TPK memiliki pemahaman terhadap konsep larutan penyangga yang lebih baik dibanding siswa yang dibelajarkan menggunakan REACT saja.

Perbedaan yang terjadi diantara dua kelas tersebut disebabkan oleh beberapa hal. Langkah-langkah pembelajaran REACT-TPK tidak hanya membuat siswa aktif dalam pembelajaran, tetapi juga mendorong terjadinya perubahan konsepsi siswa dari salah menjadi benar. Pembelajaran pada kelas eksperimen dilengkapi dengan TPK yang dirancang sesuai dengan empat kondisi terjadinya perubahan konsep menurut Posner. Pembelajaran menggunakan REACT-TPK mempertimbangkan miskonsepsi yang ada pada siswa, sedangkan pembelajaran tanpa TPK tidak. Kelas eksperimen maupun kontrol diberikan pembelajaran yang sama pada tahap relating dan experiencing, namun pada tiga tahap setelahnya berbeda. Perbedaannya dituliskan pada tabel 5.

Tabel 5. Perbedaan Pembelajaran REACT dan REACT-TPK

\begin{tabular}{cll}
\hline No. & \multicolumn{1}{c}{$\boldsymbol{R} \boldsymbol{A} \boldsymbol{C T}$} & \multicolumn{1}{c}{$\boldsymbol{R E A C T - T P K}$} \\
\hline 1. & $\begin{array}{l}\text { Pada tahapan applying, siswa menerapkan konsep } \\
\text { yang diperoleh pada tahapan sebelumnya untuk } \\
\text { menyelesaikan/memecahkan permasalahan yang } \\
\text { diberikan. }\end{array}$ & $\begin{array}{l}\text { Pada tahapan applying, siswa akan diberikan TPK bagian 1. Jadi, siswa } \\
\text { tidak hanya menerapkan konsep yang diperoleh pada tahapan sebelumnya } \\
\text { untuk menyelesaikan/memecahkan permasalahan yang diberikan, tetapi } \\
\text { juga dapat diketahui siswa mengalami miskonsepsi ataukah tidak. }\end{array}$ \\
$\begin{array}{ll}\text { Pada tahapan cooperating, siswa berdiskusi } \\
\text { kelompok untuk memecahkan persoalan kimia. }\end{array}$ & $\begin{array}{l}\text { Tahapan cooperating ini, siswa tidak hanya berdiskusi untuk memecahkan } \\
\text { persoalan kimia, akan tetapi sebelumnya diminta berdiskusi tentang TPK } \\
\text { bagian 2 yang berisi tentang keterangan miskonsepsi dari TPK bagian 1, } \\
\text { alasan mengapa jawaban tersebut termasuk miskonsepsi dan penjelasan } \\
\text { tentang konsep yang benar. Siswa yang masih bingung tentang keadaan } \\
\text { konsepnya bisa saling bertukar pikiran dengan siswa yang sudah paham. } \\
\text { Disinilah bergunanya pembagian kelompok yang heterogen. }\end{array}$ \\
$\begin{array}{l}\text { Pada tahapan transferring, siswa menggunakan } \\
\text { konsepnya untuk menyelesaikan permasalahan } \\
\text { yang lebih luas. }\end{array}$ & $\begin{array}{l}\text { Pada tahapan transferring, siswa menggunakan konsep baru (yang } \\
\text { diperoleh setelah perubahan konsep) untuk menyelesaikan permasalahan } \\
\text { yang lebih luas. }\end{array}$ \\
\hline
\end{tabular}

Berdasarkan hasil pengujian hipotesis, ada beda pemahaman konsep antara siswa berkemampuan awal tinggi dan rendah. Konsepsi baru akan lebih mudah dimengerti siswa berkemampuan awal tinggi daripada yang rendah (Schnotz \& Bannert, 2003). Kemampuan awal (KA) ialah pemahaman yang telah dimiliki siswa tentang konsep-konsep penunjang yang telah dibelajarkan sebelumnya (Bilgin \& Uzuntiryaki, 2003). KA dalam hal ini misalnya konsep asam-basa yang sudah dibelajarkan sebelum larutan penyangga. KA ini akan menjadi bekal siswa dalam menguasai konsep baru yang diajarkan, dengan kata lain materi asam-basa 
akan menjadi bekal siswa dalam memahami konsep larutan penyangga. Semakin bagus bekal yang dimiliki siswa maka siswa tersebut tidak akan kesulitan mengikuti tahapan pembelajaran selanjutnya karena siswa berkemampuan awal tinggi akan lebih mudah mencerna dan memahami konsep baru yang diberikan (Yuliana, 2015). Kesuksesan siswa dalam pembelajaran sebelumnya berbanding lurus dengan skor kemampuan awal dan skor tes akhir (Dochy, Moerkerke, \& Segers, 1999). Jika siswa telah berhasil dalam pembelajaran sebelumnya maka dapat diprediksi bahwa siswa akan lebih berhasil dalam pelajaran selanjutnya (Hailikari, Nevgi, \& Komulainen, 2008). Hal inilah alasan siswa berkemampuan awal tinggi memiliki pemahaman konsep yang lebih baik dibandingkan yang berkemampuan awal rendah.

Tidak terdapat dampak interaksi diantara model pembelajaran dengan kemampuan awal terhadap pemahaman konsep ditunjukkan pada tabel 4. Interaksi tidak terjadi ketika pengaruh suatu variabel bebas tidak tergantung pada variabel bebas yang lain dalam suatu eksperimen (Beins \& McCarthy, 2012). Profil Plot pemahaman konsep siswa pada kelas REACT dan REACTTPK ditunjukkan gambar 1 .

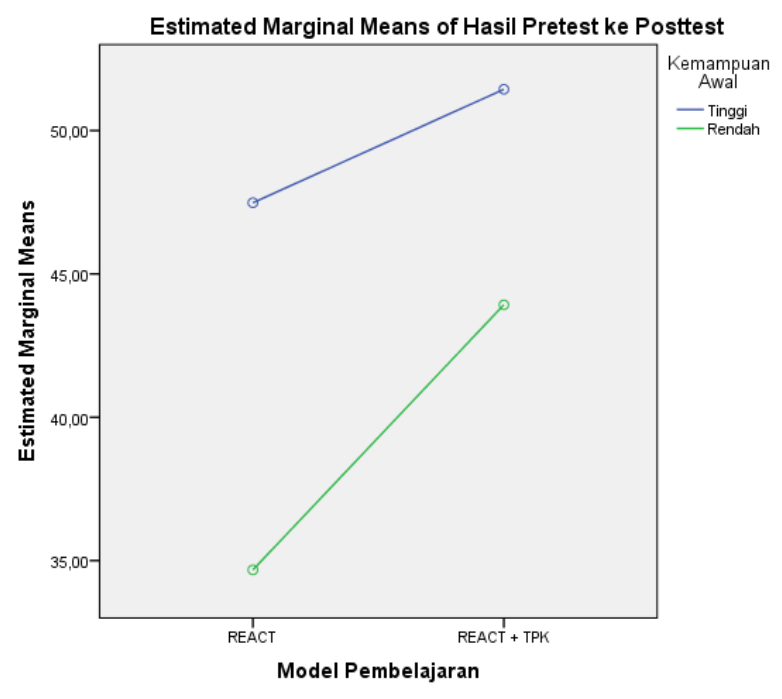

Gambar 1. Profil Plot Pemahaman Konsep

Berdasarkan gambar 1, siswa berkemampuan awal tinggi menunjukkan peningkatan pemahaman yang lebih bagus, baik ketika diajarkan dengan REACT-TPK maupun REACT saja. Selain itu, baik berkemampuan awal tinggi ataupun rendah menunjukkan peningkatan pemahaman konsep lebih bagus pada kelas yang diimplementasikan REACT-TPK dibandingkan pada kelas yang hanya dibelajarkan dengan REACT. Hal tersebut mengindikasikan bahwasanya pengaruh model pembelajaran terhadap pemahaman konsep tidak tergantung pada level kemampuan awal ataupun sebaliknya.

\section{SIMPULAN}

Kesimpulan hasil penelitian, yakni ada beda pemahaman konsep diantara siswa yang diimplementasikan model $R E A C T$ TPK dan REACT saja. Ada perbedaan pemahaman konsep antara siswa dengan kemampuan awal tinggi dan rendah pada topik larutan penyangga. Tidak ditemukan adanya dampak pengiring antara model pembelajaran dengan tingkat kemampuan awal siswa terhadap pemahaman konsep pada topik larutan penyangga.

Nilai kemampuan awal hanya diambil dari nilai ulangan harian topik sebelumnya yang berhubungan dengan topik larutan penyangga, yaitu hanya nilai ulangan harian asam basa saja. Peneliti beranggapan bahwa pengambilan nilai kemampuan awal hanya dari satu topik sebelumnya kurang mencerminkan kemampuan awal siswa sebenarnya karena ada beberapa siswa yang termasuk siswa dengan kemampuan awal tinggi, namun memiliki nilai pretest dan posttest yang cukup rendah. Nilai ulangan harian yang digunakan sebagai nilai kemampuan awal sebaiknya tidak hanya diambil dari satu topik saja, namun dari rata-rata beberapa topik yang berhubungan dengan topik kimia yang akan diteliti.

\section{DAFTAR RUJUKAN}

Ahmad, F., Gani, T., \& Tanre, M. (2017). Pengaruh Model Pembelajaran dan Kemampuan Awal terhadap Hasil Belajar Peserta Didik dalam Materi Kimia Kelas XI IPA SMAN 4 Makasar. Cemistry Education Review, 1(1), 84-91.

Ahmad., Suyono., \& Yuanita, L. (2013). Reduksi Miskonsepsi Asam Basa melalui Inkuiri Terbuka dan Strategi Conceptual Change. Jurnal Penelitian Pendidikan Sains, 3(1), 286-293. http://dx.doi.org/10.26740/jpps.v3n1.p286-293

Aprilia, I. N., \& Suyono. (2016). Penerapan Strategi Conceptual Change dengan Analogi untuk Mereduksi Miskonsepsi Ikatan Kimia Berbasis Model Mental Atribut Imajinasi. UNESA Journal of Chemical Education, 5(2), 239-247. 
Ardyanti, N., \& Nasrudin, H. (2014). Mereduksi Miskonsepsi Level Sub-Mikroskopik dan Simbolik pada Materi Hidrolisis Garam Siswa SMA Negeri 1 Bojonegoro melalui Model Pembelajaran Conceptual Change. Jurnal of Chemical Education, 3(2), 261-269.

Beerenwinkel, A., Parchmann, I., \& Grasel, C. (2011). Conceptual Change Texts in Chemistry Teaching: A Study on the Particle Model of Matter. International Journal of Science and Mathematics Education, 9(5), 1235-1259.

Beins, B. C., \& McCarthy, M. A. (2012). Research Methods and Statistics. USA: Pearson Education.

Bennett, J., Grasel, C., Parchmann, I., \& Waddington, D. (2005). Context-Based and Conventional Approaches to Teaching Chemistry: Comparing Teachers' Views. International Journal of Science Education, 27(13), 1521-1547.

Bilgin, I., \& Uzuntiryaki, E. (2003). Student's Misconceptions on the Concept of Chemical Equilibrium Öğrencilerin Kimyasal Denge Konusundaki Kavram Yanılgiları. Education and Science, 28(127), 10-17.

Cepni, S., \& Cil, E. (2010). Using a Conceptual Change Text as a Tool to Teach the Nature of Science in an Explicit Reflective Approach. Asia-Pacific Forum on Science Learning and Teaching, 11(1), 1-29.

Cetin-Dindar, A., \& Geban, O. (2017). Conceptual Understanding of Acids and Bases Concepts and Motivation to Learn chemistry. Journal of Educational Research, 110(1), 85-97.

Cetin, P. S., Kaya, E., \& Geban, O. (2009). Facilitating Conceptual Change in Gases Concepts. Journal of Science Education and Technology, 18(2), 130-137.

Cil, E., \& Cepni, S. (2016). The Effectiveness of Conceptual Change Texts and Concept Clipboards in Learning the Nature of Science. Research in Science and Technological Education, 34(1), 43-68.

Crawford, M. L. (2001). Teaching Contextually. Texas: CCI Publishing.

Demircioglu, G. (2009). Comparison of the Effects of Conceptual Change Texts Implemented After and Before Instruction on Secondary School Students' Understanding of Acid-Base Concepts. Asia-Pacific Forum on Science Learning and Teaching, 10(2), 1-29.

Dochy, F., Moerkerke, G., \& Segers, M. (1999). The Effect of Prior Knowledge on Learning in Educational Practice: Studies Using Prior Knowledge State Assessment. Evaluation and Research in Education, 13(3), 114-131.

Durmus, J., \& Bayraktar, S. (2010). Effects of Conceptual Change Texts and Laboratory Experiments on Fourth Grade Students' Understanding of Matter and Change Concepts. Journal of Science Education and Technology, $19(5), 498-504$.

Gabel, D. L., Sherwood, R. D., \& Enochs, L. (1984). Problem-Solving Skills of High School Chemistry Students. Journal of Research in Science Teaching, 21(2), 221-233.

Gunter, T. (2018). The Effect of the REACT Strategy on Students' Achievements with Regard to Solubility Equilibrium: Using Chemistry in Contexts. Chemistry Education Research and Practice, 19(4), 1287-1306.

Hailikari, T., Nevgi, A., \& Komulainen, E. (2008). Academic Self-Beliefs and Prior Knowledge as Predictors of Student Achievement in Mathematics: A Structural Model. Educational Psychology, 28(1), 59-71.

Herawati, R., Mulyani, S., \& Redjeki, T. (2013). Pembelajaran Kimia Berbasis Multiple Representasi Ditinjau dari Kemampuan Awal terhadap Prestasi Belajar Laju Reaksi Siswa SMA Negeri I Karanganyar Tahun Pelajaran 2011/2012. Jurnal Pendidikan Kimia Universitas Sebelas Maret, 2(2), 38-43.

Holme, T. A., Luxford, C. J., \& Brandriet, A. (2015). Defining Conceptual Understanding in General Chemistry. Journal of Chemical Education, 92(9), 1477-1483.

Kalchick, S., \& Oertle, K. M. (2010). The Theory and Application of Contextualized Teaching and Learning in Relation to Programs of Study and Career Pathways. Transition Highlights, (2), 1-6.

Karsli, F., \& Yigit, M. (2017). Effectiveness of the REACT Strategy on $12^{\text {th }}$ Grade Students' Understanding of the Alkenes Concept. Research in Science and Technological Education, 35(3), 274-291.

Maratusholihah, N. F., Rahayu, S., \& Fajaroh, F. (2017). Hidrolisis Garam dan Larutan Penyangga. Jurnal Pendidikan: Teori, Penelitian, dan Pengembangan, 2(7), 919-926.

Muallifah., Suyono., \& Yuanita, L. (2013). Mencegah Miskonsepsi Siswa pada Kesetimbangan Kimia menggunakan Model Inkuiri Terbuka dan Remediasi menggunakan Strategi Conceptual Change. Jurnal Pennelitian Pendidikan Sains, 3(1), 306-313. http://dx.doi.org/10.26740/jpps.v3n1.p306-313

Nakhleh, M. B. (1992). Why Some Students Don't Learn Chemistry: Chemical Misconceptions. Journal of Chemical Education, 69(3), 191-196.

Niaz, M., \& Chac'on, E. (2003). A Conceptual Change Teaching Strategy to Facilitate High School Students' Understanding of Electrochemistry. Journal of Science Education and Technology, 12(2), 129-134.

Nikmah, K., \& Suyono. (2015). Penerapan Strategi Pembelajaran Conceptual Change untuk Meremediasi Miskonsepsi pada Konsep Asam-Basa Siswa Kelas XII IPA SMAN 1 Waru Sidoarjo. UNESA Journal of Chemical Education, 4(3), 541550 .

Orgill, M. K., \& Sutherland, A. (2008). Undergraduate Chemistry Students' Perceptions of and Misconceptions about Buffers and Buffer Problems. Chemistry Education Research and Practice, 9(2), 131-143.

Posner, G. J., Strike, K. A., Hewson, P. W., \& Gertzog, W. A. (1982). Accommodation of a Scientific Conception: Toward a Theory of Conceptual Change. Science Education, 66(2), 211-227. 
Schnotz, W., \& Bannert, M. (2003). Construction and Interference in Learning from Multiple Representation. Learning and Instruction, 13(2), 141-156.

Sendur, G., \& Toprak, M. (2013). The Role of Conceptual Change Texts to Improve Students' Understanding of Alkenes. Chemistry Education Research and Practice, 14(4), 431-449.

Suminten, N. (2015). Strategi Pembelajaran Relating-Experiencing-Applying-Cooperating-Transferring (REACT) dengan Pendekatan Inkuiri untuk Mengurangi Miskonsepsi Fisika Siswa. 1(2).

Sung-Il Kim, \& Dusen, L. M. Van. (1998). The Role of Prior Knowledge and Elaboration in Text Comprehension and Memory: A Comparison of Self-Generated Elaboration and Text-Provided Elaboration. The American Journal of Psychology, $111(3), 353-378$.

Ultay, N., Durukan, U. G., \& Ultay, E. (2015). Evaluation of the Effectiveness of Conceptual Change Texts in the REACT Strategy. Chemistry Education Research and Practice, 16(1), 22-38.

Yuruk, N. (2007). The Effect of Supplementing Instruction with Conceptual Change Texts on Students' Conceptions of Electrochemical Cells. Journal of Science Education and Technology, 16(6), 515-523.

Yuliana, I. F. (2015). Pengaruh Inkuiri Terbimbing dengan Intertekstual terhadap Hasil Belajar Materi Kesetimbangan Kimia dan Literasi Kimia Ditinjau dari Kemampuan Awal. Tesis tidak diterbitkan. Universitas Negeri Malang, Malang. 